УДК $519.6+612.1$

\title{
A system for monitoring the state of human cardiovascular system based on the most complete mathematical model of vascular bed
}

\author{
E.N. Solovyova ${ }^{1}$, N.N. Kizilova ${ }^{2}$ \\ ${ }^{I}$ Kharkiv National Technical University 'KhPI', Kirpichova 2, 61002, Kharkiv, Ukraine \\ ${ }^{2}$ Kharkiv National University V.N. Karazina, Svobody Sq 4, 61022, Kharkiv, Ukraine \\ e-mail: helenfilippova@yahoo.co.uk
}

\begin{abstract}
The structure of a new system for monitoring the state of the human cardiovascular system based on geometric and biomechanical models of the vascular bed as a branching tree of arteries is presented. The tree geometry has been obtained by averaging the data of postmortem measurements from five bodies, a statistical analysis of the patterns of the structure of vascular trees, and a new technique for generating an individual tree for a particular patient by performing several in vivo measurements. The developed biomechanical model allows for numerical calculations of pressures and blood flow velocities in each artery, storing information in a database, analyzing the distribution of blood volumes, calculating important diagnostic indices, identifying pathologies and planning surgical operations in silico.
\end{abstract}

Ключові слова: monitoring system, cardiovascular system, mathematical modeling, database, medical diagnostics.

У статті наведена структура нової системи моніторингу стану серцево-судинної системи людини на основі геометричної і біомеханічної моделей судинного русла як розгалуженого дерева артерій. В роботі викладені підходи, моделі і методи, які є компонентами нової системи моніторингу стану здоров'я людини. Геометрія дерева отримана шляхом усереднення даних вимірювань postmortem на п'яти тілах, статистичному аналізі закономірностей будови судинних дерев. Представлена нова методика генерації індивідуального дерева конкретного пацієнта та граничних умов для нього (термінальні мікроциркуляторні русла) шляхом виконання декількох вимірювань in vivo, 3 урахуванням віку, а також результатів біохімічного та клінічного аналізу крові. Для проведення чисельних розрахунків використовувалася модель, яка базується на рівняннях Нав'є-Стокса для вісесиметричних течій в'язкої нестисливої рідини і системи рівнянь класичної теорії в'язкопружньої товстостінної трубки для реологічної моделі Кельвіна-Фойхта для матеріалу стінки судин, 3 урахуванням умови безперервності тиску і витрати рідини на біфуркаціях трубок, при чому на відкритих кінцях трубок моделі задавалися термінальні провідності мікроциркуляторних русел органів. Була проведена валідація математичної моделі на основі експериментальних даних і корекція значень реологічних параметрів моделей методом найменших квадратів. Розроблена біомеханічна модель дозволяє проводити чисельні розрахунки тисків і швидкостей кровотоку в кожної артерії, зберігати інформацію в базі даних, аналізувати розподіл об’ємів крові та швидкостей кровотоку, розраховувати важливі діагностичні індекси, планувати терапевтичне або хірургічне лікування недостатності кровообігу 3 кількісною оцінкою результатів лікування in silico.

Ключевые слова: система моніторингу, сериево-судинна система, математичне моделювання, база даних, медична діагностика.

В статье представлена структура новой системы мониторинга состояния сердечно-сосудистой системы человека на основе геометрической и биомеханической моделей сосудистого русла как ветвящегося дерева артерий. Геометрия дерева получена на основании усреднения данных измерений postmortem на пяти телах, статистическом анализе закономерностей строения сосудистых деревьев, новой методике генерации индивидуального дерева конкретного пациента путем выполнения нескольких измерений in vivo. Разработанная биомеханическая модель позволяет проводить численные расчеты давлений и скоростей кровотока в каждой артерии, хранить информацию в базе данных, анализировать распределение объемов крови, скорости кровотока, рассчитывать важные диагностические индексы, выявлять нарушения и планировать хирургические операции in silico.

Keywords: система мониторинга, сердечно-сосудистая система, математическое моделирование, база данных, медицинская диагностика.

\section{Introduction}

New technologies developed in physics, chemistry, material and computer sciences have considerably changed our everyday life. During the last decades revolutionary in silico methods of medical diagnostics, quantitative planning of surgery, treatment and rehabilitation based on computerassisted systems, medical data analysis, mathematical models, artificial intelligence (AI) and decision support systems have changed the quality of healthcare [1-3]. The newest medical apparatus and systems makes it possible to obtain detailed $3 \mathrm{~d}$ images of blood vessels and inner organs (CT, MRI), to measure pressure $\mathrm{P}(\mathrm{t})$ and blood flow velocity $\mathrm{V}(\mathrm{t})$ in the vessels, and other information on physical and biochemical processes in the organism. Thus, the method of photoplethysmography with finger sensors allows registration of arterial pressure continuously with receiving big datasets. The most popular system Finapres (FINger Arterial PRESsure) (Fig.1a) was developed in 1980 [4]. Later, 
Finometer, Portapres (FMS) and Nexfin appeared at the market. More complicated systems such as collection of monitors presented by two finger sensors, one wrist pressure sensor and cuff manometer for brachial artery have been recently introduced [5]. The long-term measurements makes it possible to define the heart rate, heart rate variability (HRV), short respiratory and long circadian waves, the pulse shape and many other parameters. HRV gives important information on the heart health. The corresponding spectral, fractal, wavelet analyses, Lyapunov exponent, entropy and other important diagnostic indices could be calculated based on the registered curves [5, 6].

In recent years portable sensors (Fig. 1b) and mobile applications (mobile apps), based on sensor panels of mobile phones and pads (Fig. 1c) or interacting with it through infrared port are getting popular. The measurements of optical transmission oscillations through finger tips with the help of a smartphone sensor panel allow us to register pressure and temperature curves, store and analyze them with corresponding software, and send to a doctor for monitoring the current state of the patient. Thus, the opportunity of continuous registration as time series of many human cardiovascular system parameters is essential for detailed and timely medical diagnostic. It requires the development of new approaches for the formats, the methods of encryption, the storage, the extraction, the statistical analysis and the biomechanical interpretation of the data measured as well as the elaboration of corresponding mathematical models, big data analysis, AI, and other mathematical approaches [7]. Thus medicine is becoming multidisciplinary science, which requires the participation of mathematicians, mechanics, and physicians for elaborating new methods for data processing and analysis of mathematical models of physical processes of a human organism.

In this work a new system for monitoring the state of human cardiovascular system based on the medical data analyses and mathematical modeling of the blood flow and pulse wave propagation along the vasculature system of particular patient is proposed. Similar modeling of systemic arteries as a binary tree composed by 55 elastic tubes (aorta and its branching, carotid arteries, high and low extremities) was proposed in [8]. The models of upper limbs vessels [9], a brain [10], coronary arteries [11] and an aorta [12] have also been developed and used for numerical computations of blood flow distributions and wave travel along the system. The vascular model presented in the proposed monitoring system is the most complete and allows obtaining valuable diagnostic information via real time numerical calculations (10-20 min).
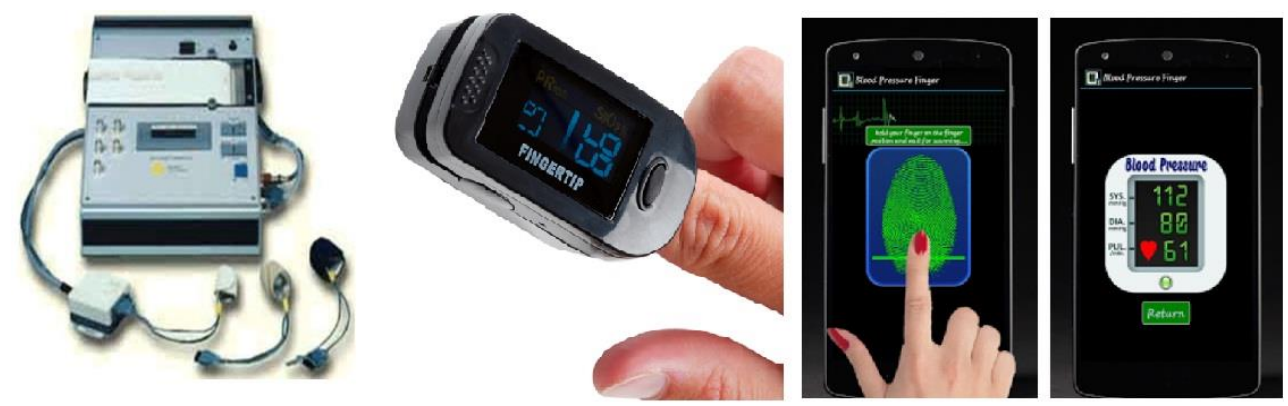

Fig. 1. The finger sensors of pressure Checker Prank (Superior Technologies, Inc.) (a), Finger BP (SmartApps Ltd.) (b), and Blood Pressure Finger Prank (Google Play) (c).

\section{2. Components of the monitoring system}

2.1. Geometry model of human circulatory system and database.

The results of detailed postmortem opening measurements on 5 bodies (with age ranging from 38 to

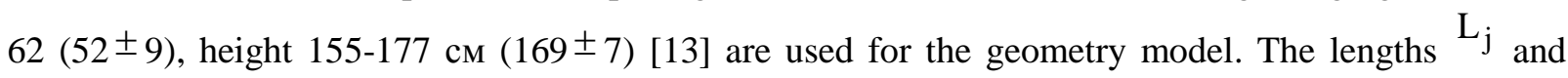
diameters $d_{j}$ of systemic (intraorgan) arteries have been measured on visible arteries of the body and on plastic casts of inner organs and muscles. The results have been stored in the database DB1. In the 5 datasets different numbers (from 870 to 1027) of the extraorgan arteries have been measured, since the structure of systemic vasculatures has considerable individual features [14]. The measured data for the aorta and its branches (93 segments) are given as a table in [12]. For the vasculatures of inner organs the lengths and diameters of $>10^{4}$ arteries till to the segments with $\mathrm{d}^{*}=0.1 \mathrm{~mm}$ have been measured [13]. 
The statistical analysis of the measured diameters and lengths has revealed statistically significant dependences $\left(\mathrm{R}^{2}>0.87\right)$ between the diameters in both bifurcations and trifurcations (Murray's law) in the systemic arteries [12] and in the inner organs [11]. The artery lengths have been normalized by the individual's height, and the inner diameters have been recomputed to have the tubes of circular cross sections with the same hydraulic conductivities as in the raw data geometry. Less significant correlations $\left(R^{2}>0.64\right)$ have been found between $L_{j}$ and $d_{j}$ [13]. The obtained statistical dependences allow restoration of any individual arterial vasculature up to the vessels of diameter $\mathrm{d}^{*}[11,16,17]$ from the measured diameters of the aortic segments and feeding arteries of inner organs. The restored models of some of the inner organs are presented in Fig.2.

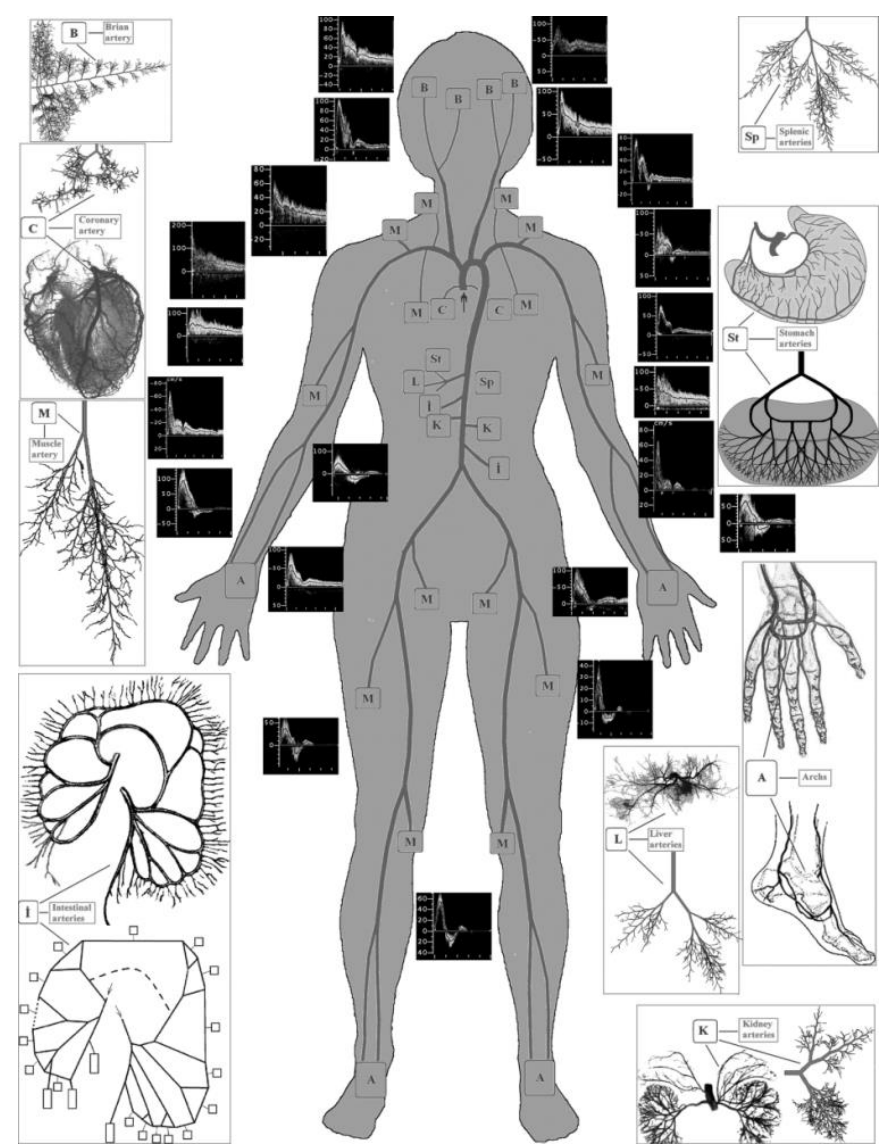

Fig.2. The scheme of systemic arterial tree, arteries of inner organs and muscles, and their restored models.

The systemic trees of five individuals with normalized lengths and diameters after comparison have been averaged, and the averaged geometric model of human systemic tree composed by 970 tubes has been built and stored in DB1. This model makes it possible to recalculate parameters of all tubes for an individual patient.

Similar ultrasound measurements (USG) have been done on five health volunteers (with age ranging from 31 to 10, height 155-177 см (168 \pm 5$)$ ) [15]. The measurements of $L_{j}$ and $d_{j}$ values and the Doppler blood flow curves have been done in 67 segments of the systemic arteries (Fig.1). The measured values have been recorded in database DB2 and used for validation of the restored models of arterial beds of volunteers based on the averaged model from DB1. The statistical analysis of DB2 has found the dependences between the values of $L_{j}$ and $d_{j}$ in the arterial bifurcations similar to the corresponding statistical dependencies computed on DB1 [15].

\subsection{Mathematical model of human vascular bed}

For numerical calculations of the $\mathrm{P}(\mathrm{t})$ and $\mathrm{V}(\mathrm{t})$ curves on the geometry models of systemic bed (55tube), coronary, brain arteries and some other beds [8-10], 1D models of linear theory of plane waves in arteries developed by Sir J. Lighthill, 2D model of axisymmetric flow (cylindrical waves) based on the linearized Navier-Stokes equations, numerical solutions of 3D turbulent flow equations in tubes 
with arbitrary geometry and rigid or compliant walls by finite element method can be used. The latter approach requires several months of calculations on big cluster even for 55 tubes and gives the results of comparable accuracy with simpler and faster 1D and 2D models [18]. In this monitoring system the mathematical model based on Navier-Stokes equations for axisymmetric flows of viscous incompressible fluid for blood, and the system of equations of classical theory of viscoelastic wall with Kelvin-Voight rheology for the vessel wall material have been used [7,11,12,15-17]. At the bifurcations the pressure and blood flow continuity condition have been applied. At the entrance to the system (aortic root) the pressure curve $\mathrm{P}(\mathrm{t})$ generated by the heart contraction can be taken either in the standard averaged shape [15-18] or from the measurement data of the particular patient. At the open ends of the tubes (Fig.2) the terminal conductivities of the microcirculatory beds of the inner organs and muscles could be assigned (see the table of typical values in [18]). The terminal wave reflection coefficients $G_{j}=G_{j}^{\prime}+i G_{j}^{\prime \prime}$, where real $G_{j}^{\prime}$ and imaginary $G_{j}^{\prime}$ parts correspond to the resistive and capacity properties of the microcirculatory bed could also be used $[12,15-17]$. The values of $G_{j}$ have been calculated for each terminal tube as for in vitro 1000-tube model as in vivo 67-tube model based on the averaged datasets and statistical dependences from DB1 [13].

The values of density, Young's modulus and viscosity of the vessel walls have been obtained from statistical approximations of big datasets measured on arterial segments in available literature. The data can be presented in the form of statistical dependences of the material parameters on the vessel diameter, the age of person and type of a cardiovascular disease (hypertension, atherosclerosis, etc.). The density and viscosity of blood can be measured on a patient's blood sample.

The solution of the Navier-Stokes and viscoelastic wall equations in each tube of the model has been found as a composition of the forward and reflected waves. The linearized 2D model allows fast numerical computations on the $\sim 1000$-tree model in the form Fourier expansion (the calculation time $<10 \mathrm{~min})$. Validation of the proposed mathematical model has been done using Doppler ultrasound curves $\mathrm{V}(\mathrm{t})$ from DB2. The correction of the values of rheological parameters of the individual models has been carried out by the least square method.

\section{The results of work of the monitoring system}

The methods and approaches developed in the proposed monitoring system are presented graphically in Fig.3.

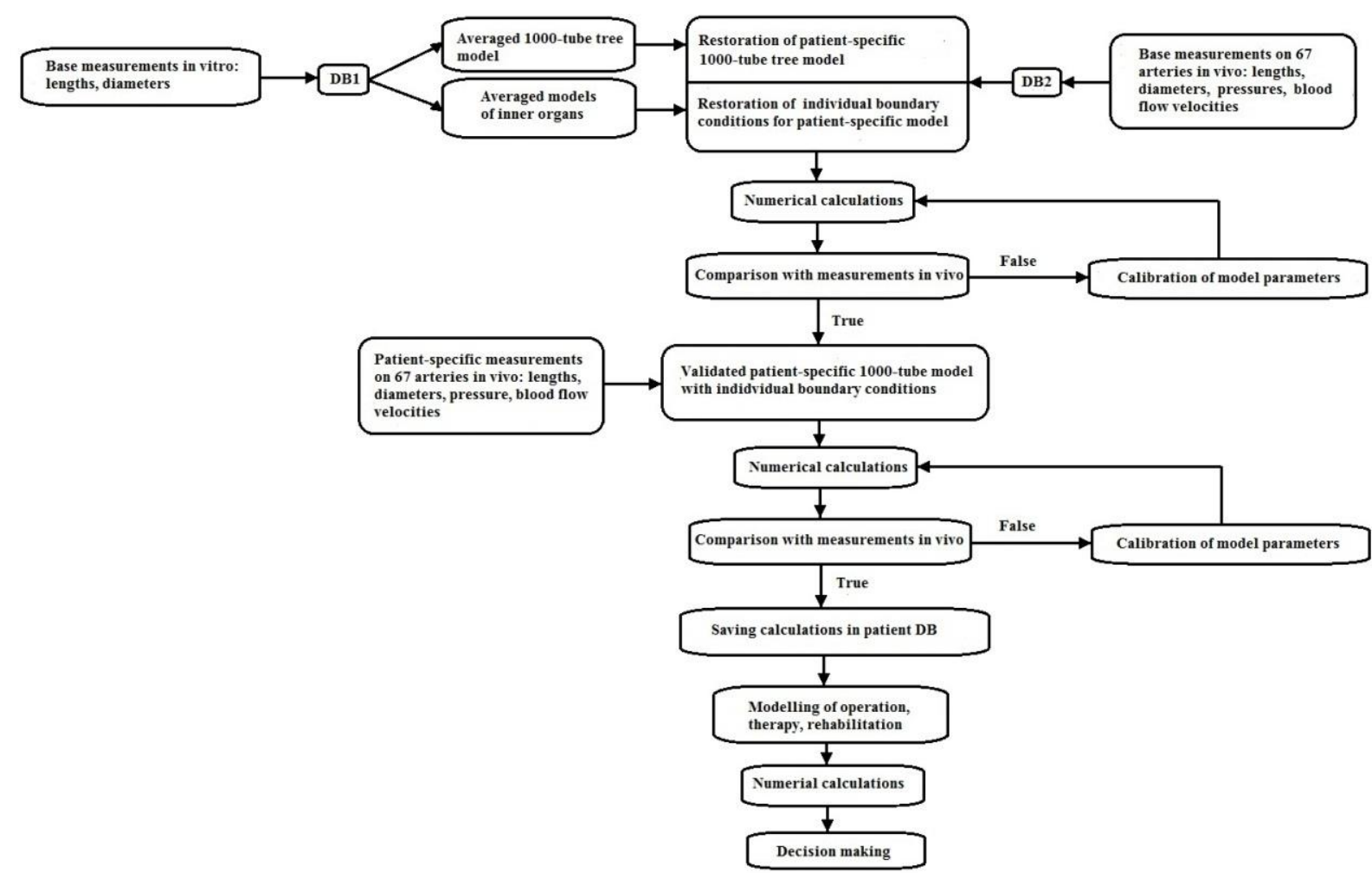

Fig. 3. The structure and principles of work of the monitoring system. 
The developed monitoring system has been used for the modeling of pulse wave propagation and reflection, blood pressure wave evolution along the aorta, and blood flow distribution between inner organs $[12,15]$ on the most complete model of aorta composed by 93 tubes, obtained in the correspondence to the presented algorithms (Fig.3) based on the data from DB1.

\section{Conclusion}

The approaches, models and methods that are components of the novel monitoring system of the state of human health, in silico planning of therapeutic and surgical treatment of circulatory diseases via quantitative evaluation of the treatment outcomes based on geometric and biomechanical models of human circulatory system as a complex branching arterial tree are presented. The algorithm of restoration of the individual 1000-tube model of systemic arterial bed and the boundary conditions (terminal microcirculatory bed) for numerical calculations, corrections of the individual model parameters using the personal data available (biochemical and clinical blood examination, CT, MRI, USG, et. al.) has been elaborated.

The presented monitoring system allows numerical calculations of the blood pressure and blood flow velocity in each artery; storing information as measurement and calculated datasets; calculations and analyses of the important diagnostic indices; decision support for diagnostics of local and global vascular impairments. The developed monitoring system can accumulate valuable information either for one patient in the course of long repeated monitoring or for a certain group of diseases that could be analyzed later by the methods of Big Data analysis and AI for independent expert assessment of the health state and decision making to pinpoint the most appropriate individual therapy or surgery.

\section{ЛІТЕРАТУРА}

1. Yu K, et al. Artificial intelligence in healthcare. Nature Biomedical Engineering. 2018. Vol. 2. P. 719-731.

2. Lynch C.J. and C Liston. New machine-learning technologies for computer-aided diagnosis. Nature Medicine. 2018. vol.24. P. 1304-1305.

3. LeCun Y, et al. Deep learning. Nature. 2015. Vol. 521. P. 436-444.

4. Imholz B.P., Wieling W., van Montfrans G.A. Wesseling K.H. Fifteen years experience with finger arterial pressure monitoring: assessment of the technology. Cardiovasc Res. 1998. vol. 38. P. 605-616.

5. Chung E., Chen G., Alexander B., Cannesson M. Non-invasive continuous blood pressure monitoring: A review of current applications. Front Med. 2013. vol. 7. P.91-101.

6. Milnor WR. Hemodynamics. Baltimore: Williams\&Wilkins; 1989.

7. Kizilova N.N., Philippova E.N., Zenin O.K. From the 55-tube Westerhof's to Novel 1000-tube Model of the Human Systemic Arterial Tree: Blood Flow, Wave Propagation, Wave-Intensity Analysis and Medical Diagnostics. Proc. of ESB Congress. Edinburg. 2010. P.953.

8. Westerhof N., Bosman F., de Vries C.J., Noordegraaf A. Analog studies of the human systemic arterial tree. Journal of Biomechanics. 1969. vol. 2. P. 121-143.

9. Alastruey J., Parker K.H., Peiró J., Sherwin S.J. Can the modified Allen's test always detect sufficient collateral flow in the hand? A computational study, computer methods in biomechanics and biomedical Engineering. 2006. vol. 9. P. 353-361.

10. Alastruey J., Parker K.H., Peiró J., et al. Modelling the circle of Willis to assess the effects of anatomical variations and occlusions on cerebral flows. Journal of Biomechanics. 2007. vol.40. P.1794-1805.

11. Zenin O.K., Kizilova N.N., Philippova E.N. Studies on the Structure of Human Coronary Vasculature. Biophysics. 2007. vol. 52, N. 5. P.499-503.

12. Kizilova N., Solovyova H., Mizerski J. Modeling of pulse wave propagation and reflection along human aorta, Biomechanics in Medicine and Biology, K. Arkusz, R.Będziński, T. Klekiel, S. Piszczatowski (eds.), SpringerSeries "Advances in Intelligent Systems and Computing". 2019. vol. 831. P. 23-35.

13. Зенин О.К., Гусак В.К., Кирьякулов Г.С. Артериальная система человека в цифрах и формулах. Донецк. 2002. 198c. 
14. Лужа Д. Рентгеновская анатомия сосудистой системы. Издательство: АН Венгрии, 1973. $380 \mathrm{c}$.

15. Kizilova N., Philippova H., Zenin O. A realistic model of human arterial system: blood flow distribution, pulse wave propagation and modeling of pathology. Mechanics in Medicine. Korzynskiego M., Cwanka J. (eds). Rzeszow. 2010. Vol.10. P.103-118.

16. Балабанов В.О., Кізілова Н.М. Математичне моделювання стаціонарної та хвильової провідності артеріальних систем як бінарних дерев. Вісник КНУ імені Т.Г.Шевченко. Серія «Фізико-математичні науки». 2017. N3. C.19-23.

17. Балабанов В.А., Кизилова Н.Н. Исследование пространственного распределения крови по дереву коронарных артерий: влияние геометрии и режима течения. 3б. праць XVIII Міжнародного симпозіуму «Методи дискретних особливостей в задачах математичної фізики» (МДОЗМФ-2017). Харків. 2017. С. 32-36.

18. Xiao N., Alastruey J., Alberto F.C. A systematic comparison between 1-D and 3-D hemodynamics in compliant arterial models. Int. J. Numer. Method. Biomed. Eng. 2014. vol.30, N2. P.204-31.

\section{REFERENCES}

1. $\mathrm{Yu} \mathrm{K}$, et al. "Artificial intelligence in healthcare." Nature Biomedical Engineering, vol. 2, pp. 719-731. 2018.

2. Lynch C.J. and C. Liston. "New machine-learning technologies for computer-aided diagnosis." Nature Medicine, vol. 24, pp. 1304-1305, 2018.

3. LeCun Y, et al. "Deep learning" Nature, vol.52, pp. 436-444, 2015.

4. Imholz B.P., Wieling W., van Montfrans G.A., Wesseling K.H.” Fifteen years experience with finger arterial pressure monitoring: assessment of the technology." Cardiovasc Res, vol.38, pp. 605-616, 1998.

5. Chung E., Chen G., Alexander B., Cannesson M. "Non-invasive continuous blood pressure monitoring: A review of current applications." Front Med. vol.7, pp.91-101, 2013.

6. Milnor WR. "Hemodynamics." Baltimore: Williams\&Wilkins; 1989.

7. Kizilova N.N., Philippova E.N., Zenin O.K. "From the 55-tube Westerhof's to Novel 1000-tube Model of the Human Systemic Arterial Tree: Blood Flow, Wave Propagation, Wave-Intensity Analysis and Medical Diagnostics." Proc. of ESB Congress, Edinburg, P.953, 2010.

8. Westerhof N., Bosman F., de Vries C.J., Noordegraaf A. "Analog studies of the human systemic arterial tree." Journal of Biomechanics, vol. 2,. pp.121-143, 1969.

9. Alastruey J., Parker K.H., Peiró J., Sherwin S.J. "Can the modified Allen's test always detect sufficient collateral flow in the hand?" A computational study, Computer Methods in Biomechanics and Biomedical Engineering. vol. 9, pp. 353-361, 2006.

10. Alastruey J., Parker K.H., Peiró J., et al. "Modelling the circle of Willis to assess the effects of anatomical variations and occlusions on cerebral flows". Journal of Biomechanics, vol. 40, pp. 1794-1805, 2007.

11. Zenin O.K., Kizilova N.N., Philippova E.N. "Studies on the Structure of Human Coronary Vasculature." Biophysics, vol. 52, no. 5, pp.499-503, 2007.

12. Kizilova N., Solovyova H., Mizerski J. "Modeling of pulse wave propagation and reflection along human aorta". Biomechanics in Medicine and Biology, K. Arkusz, R.Będziński, T. Klekiel, S. Piszczatowski (eds.), Springer Series “Advances in Intelligent Systems and Computing”, vol. 831, pp. 23-35, 2019.

13. Zenin O.K., Gusak V.K., Kiryakulov G.S. "Arterial system of human in numbers and formulas. Donetsk, 198 p, 2002. [in Russian]

14. Luzha D. Лужа Д. X-ray anatomy of the vascular system. Hungarian publishing house, 380 p, 1973. [in Russian]

15. Kizilova N., Philippova H., Zenin O. "A realistic model of human arterial system: blood flow distribution, pulse wave propagation and modeling of pathology. "Mechanics in Medicine. Korzynskiego M., Cwanka J. (eds). Rzeszow, vol.10, pp.103-118, 2010.

16. Balabanov V.O., Kizilova N.M. "Mathematical modeling of hydraulic conductivity and wave propagation of arterial systems as binary trees." Bulletin of the Taras Shevchenko National University. Physical and Mathematical Sciences Series. no.3, pp. 19-23, 
2017. [in Ukrainian]

17. Balabanov V.A., Kizilova N.N. "Investigation of the spatial distribution of blood along the coronary artery tree: the influence of geometry and flow regime." Coll. Proceedings of the XVIII International Symposium "Methods of Discrete Features in Mathematical Physics Problems" (MDOSMF-2017). Kharkiv, pp. 32-36, 2017. [in Russian]

18. Xiao N., Alastruey J., Alberto F.C. "A systematic comparison between 1-D and 3-D hemodynamics in compliant arterial models.” Int. J. Numer. Method. Biomed. Eng. v.30, no 2, pp. 204-31, 2014.

Кізілова Наталія Миколаӥвна - доктор фізико-математичних наук, професор кафедри прикладної математики, Харківський начіональний університет імені В. Н. Каразіна, майдан Свободи, 4, Харків-22, Україна, 61022;

e-mail: n.kizilova@gmail.com; ORCID: 0000-0001-9981-7616.

Kizilova Natalya N. Doctor of Science, Professor of Department of Applied Mathematics V.N. Karasin Kharkiv National University, Svobody Sq 4, 61022, Kharkiv, Ukraine; e-mail: n.kizilova@gmail.com; ORCID: 0000-0001-9981-7616.

Кизилова Наталья Николаевна - доктор физико-математических наук, профессор кафедры прикладной математики, Харьковский национальный университет имени В. Н. Каразина, площадь Свободы, 4, Харьков-22, Украина, 61022

e-mail: n.kizilova@gmail.com; ORCID: 0000-0001-9981-7616.

Соловйова Олена Миколаӥвна - викладач кафедри вищої математики, Харківський начіональний технічний університет «Харківський політехнічний інститут», вул. Кирпичова 2, Харків, Украӥна, 61002;

e-mail: helenfilippova@yahoo.co.uk; ORCID: 0000-0003-3704-8350.

Solovyova Elena N. lecturer of Department of High Mathematics, Kharkiv National Technical University 'KhPI', Kirpichova 2, Kharkiv, Ukraine, 61002.

e-mail: helenfilippova@yahoo.co.uk; ORCID: 0000-0003-3704-8350.

Соловьева Елена Николаевна - преподаватель кафедры высшей математики, Харьковский национальный технический университет «Харьковский политехнический институт», ул. Кирпичева 2, Харьков, Украина, 61002;

e-mail: helenfilippova@yahoo.co.uk; ORCID: 0000-0003-3704-8350. 